\title{
The role of goal-setting theory on Iranian EFL learners' motivation and self-efficacy
}

Hosseini Fatemi, Azar

Ferdowsi University of Mashhad, Iran (hfatemi@ferdowsi.um.ac.ir)

Pishghadam, Reza

Ferdowsi University of Mashhad, Iran (pishghadam@um.ac.ir)

Vahidnia, Fatemeh $\bowtie$

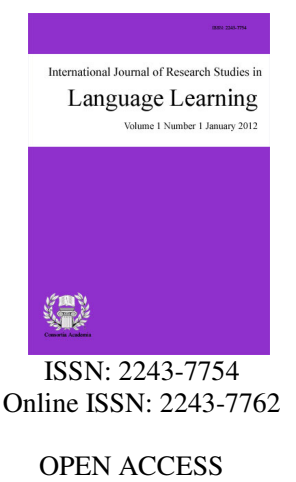

Ferdowsi University of Mashhad,Iran (Fateme.vahidnia@yahoo.com)

\section{Abstract}

The present study is concerned with examining the role of goal-setting theory on Iranian EFL learners' motivation and self-efficacy. To this end, 93 EFL students were selected to take an essay exam and fill out motivation, English, and General self-efficacy scales. Multivariate analysis of variance (MANOVA) was conducted to the data. The findings of the study revealed that those learners who enjoyed higher English and General self-efficacy selected the most challenging goal. Moreover, intrinsically motivated learners opted for the high goal, extrinsically motivated students tended to choose moderate goal; however, amotivated students were more likely to pick the easy goal. This study suggests that goal-setting theory can be considered as an effective strategy for pedagogical purposes.

Keywords: English self-efficacy; general self-efficacy; goal-setting theory; motivation; EFL learners 


\section{The role of goal-setting theory on Iranian EFL learners' motivation and self-efficacy}

\section{Introduction}

A large bulk of studies in learning and cognition has substantiated the influential role of affective factors in EFL learning. As such, for any educational programs to be successful, these factors ought to be taken into account. Additionally, understanding how to keep students involved in learning is a critical issue. To do this, we need to know the underlying mechanisms of motivation to design programs in order to promote it. The importance of motivation lies in the fact that not only does it make a contribution to achievement, but also it is important by itself as an outcome (William \& Burden, 1997).

In spite of the above-mentioned significance of affective factors in students' learning process and to our best knowledge, there are as yet areas of investigation for which either no or few researches have been conducted in Iran to examine this relationship. One such area relates to examining the role of Iranian university students' choice of goals in their self-efficacy and motivation. In other words, this study is about to explore the possible difference among learners' self-efficacy and motivation in terms of their choice of goals.

\section{Literature Review}

\subsection{Motivation}

Educational psychologists have long recognized the value of the concept of motivation in the process of learning (William \& Burden, 1997). To quote Pintrich and Schunk, "Motivation is the process whereby goal-directed activity is instigated and sustained" (1996, p. 5). To satisfy the needs of the learners, teachers draw on motivation. A possible reason behind this fact is that, in order to be engrossed and committed to the lesson, language learners ought to be motivated. As a matter of fact, Linnenbrink and Pintrich (2003) affirmed that teachers feel concern for students' motivation because sentiments and beliefs about interest and worth help students to be more engaged, leading to a higher quality of experience and learning. Accordingly, in the case of being motivated in a positive way, students will tend to be more inclined to take initiative to make positive choices. Based on the self-determination framework, there are three orientations to motivation: intrinsic motivation, extrinsic motivation, and amotivation. These types of motivation are not categorically dissimilar; however, they are situated on a continuum of increasing self-determination.

\subsection{Intrinsic Motivation}

According to Ryan and Deci (2000a), "Intrinsic motivation is defined as the doing of an activity for its inherent satisfaction rather than for some separable consequences" (pp. 56). Deci and Ryan (1985) assert that intrinsic motivation has the potentiality to be a significant stimulus of the educational process: "Intrinsic motivation is in evidence whenever students' natural curiosity and interest energize their learning" (p. 245). Students who are intrinsically motivated tend to show greater persistence to achieve their goals (Vansteenkiste, Lens, \& Deci, 2006), are more likely to be cognitively involved (Deci \& Ryan, 1985). In addition, they perform successfully, exert considerable effort in learning, and enjoy a profound level of processing while learning (Deci \& Ryan, 1985; Vansteenkiste et al., 2006). They spontaneously choose to conduct a challenging activity and eagerly seek for interesting situations to promote their capabilities (Deci \& Ryan, 1985).

\subsection{Extrinsic Motivation}

Extrinsic motivation refers to doing "something because of an external reward that may be obtained" (Schmidt, Boraie, \& Kassabgy, 1996, p. 14). Extrinsically motivated students are expected to involve in surface 
The role of goal-setting theory on Iranian EFL learners' motivation and self-efficacy

learning and tend to give up as soon as extrinsic rewards are removed. Additionally, they usually compare their performances with others irrespective of task interest and they are likely to prove their competence (Miller, Ferguson, \& Simpson, 1998). Furthermore, there is a good evidence that extrinsically motivated students opt for moderate goal (Elliot, 1999; Pintrich, 2000b).

\subsection{Amotivation}

Finding no relation between their actions and later results of those actions, students become amotivated. Amotivated language students think that studying L2 is just waste of time. They do not show persistence, do not regard language learning useful, do not feel competent in doing it, and do not believe in their success as well (Ryan \& Deci, 2000b). In addition, they do not tend to exert much effort in doing an activity; as a result they are expected to relinquish promptly (Noels, 2001).

\subsection{Self-efficacy}

Bandura defined self-efficacy as "beliefs in one's capability to organize and execute the courses of action required to manage prospective situations and to produce given attainments" (1986, p. 392). According to Bandura (1986), "Many students have difficulty in school not because they are incapable of performing successfully, but because they are incapable of believing that they can perform successfully" (p. 390). Bandura contend that self-efficacious students embrace difficult and challenging tasks than do inefficacious students (1993). However, as Bandura (1986) and Seifert (2004) maintained, individuals who enjoyed low self-efficacy for learning avoided difficult tasks and selected the easy ones.

Self-efficacy exerts a powerful effect on students' task persistence, task interest, the choices they make and the goals they set (Lent, Brown, \& Hackett, 2002; Linnenbrink \& Pintrich, 2003; Schunk, 2003; Zimmerman, Bandura, \& Martinez-Pons, 1992). Furthermore, there is an evidence that the more efficacious students are more likely to welcome the more challenging goals (Zimmerman et al., 1992). Likewise, sociocognitive theory demonstrates that high self-efficacy can encourage individuals to embrace higher levels of goals over time (Locke \& Latham, 1990). In addition, Bandura argued (1993) that individuals with high self-efficacy tended to pick difficult goals compared with those with low self-efficacy.

As of now, vast volume of evidence has demonstrated that self-efficacy positively associates with motivation and performance (Bandura \& Locke, 2003; Chemers, Hu, \& Garcia, 2001; Mills, Pajares, \& Herron, 2006; Pajares, 2002; Vancouver, Thompson, \& Williams, 2001; Webb-Williams, 2006; Zimmerman et al., 1992). As a case in point, in 1992, Zimmerman et al. exhibited that students' recent academic self-efficacy and future goal-setting were associated with prior grade achievement. In their study, personal goals of students had a significant effect on their academic achievement.

Further studies have also done to contribute to the literature within an EFL context (Eslami \& Fatahi, 2008; Heidari, Izadi, \& Vahed Ahmadian, 2012; Naseri \& Zaferanieh, 2012; Rahimi \& Abedini, 2009; Rahimpur \& Nariman-Jahan, 2010; Zare \& Davoudi Mobarakeh, 2011). They all found that self-efficacy and motivation were positively related to students' academic achievement. For example, Hosseini Fatemi and Vahidnia (2013) examined the association between Iranian EFL learners' motivation and self-efficacy. Results of their study revealed a significant association between EFL learners' self-efficacy and their motivation. In the same fashion, Ghonsooly, Elahi, and Golparvar (2012) found that university students' self-efficacy was significantly and positively related to their achievement in general English course. Likewise, Rahemi (2007) argued that self-efficacy was positively related to EFL achievements. In a related vein of research, Datu (2013) showed that students' well-being was significantly associated with their self-efficacy.

\subsection{Goal-Setting}

"A goal is what the individual is trying to accomplish, the object or aim of an action" (Lock, Shaw, Saari, \& 
Latham, 1981). Goal-setting is a fundamental element of social learning theory (Bandura, 1977). Students set some goals as gaining skills and knowledge, completing work, and getting good scores in the beginning of an activity. In the course of the activity, students monitor, evaluate, and respond to their perceptions of goal progress (Bandura, 1988; Locke \& Latham, 1990). In the case of trying to achieve a goal, people tend to evaluate their performances with the goals while working on the task. Self-evaluations of progress result in increasing self-efficacy and maintaining motivation. Thus, goals encourage people to invest much effort and show persistence, and they make people concentrate their attention on relevant task features and the strategies which facilitate their succeeding in the task (Locke \& Latham, 1990).

An important distinction made by this theory is between two types of goal orientation (Dweck, 1998; Maehr \& Midgley, 1991): performance vs. task-goal orientation (also called mastery- and learning-goal orientation).

Learning goal oriented students tend to get well at a task and do not focus on how many mistakes they make or how they look in the eyes of others (Pintrich \& Schunk, 2002). They want to be capable, gain more knowledge, and master the task. They are more likely to select challenging tasks for themselves (Elliot, 1999; Pintrich, 2000a, 2000c). They are considered as self-efficacious and are involved in progress and intrinsic motivation.

On the other hand, performance goal oriented students focus their attention on attaining high grades and appearing smart in the eyes of peers and authority figures. They tend to demonstrate high ability or to avoid failure. They may frequently draw a comparison between their scores and others and select easy tasks to improve their scores (Elliot, 1999; Maehr \& Zusho, 2009; Pintrich, 2000a).

\subsection{Goals, Self-Efficacy, and Performance}

A significant additional area to consider is the significance of goals and their interplay with self-efficacy and performance. As soon as assigning a goal, students feel a sense of self-efficacy to attain it. This sense of self-efficacy is exhibited while they work at the task and watch their goal progress (Bandura \& Cervone, 1983; Locke et al., 1981). Moreover, copious of research lends support to the value of goals in boosting students' self-efficacy, motivation, and achievement (Bandura, 1986, 1988; Locke \& Latham, 1990). Hence, it can be inferred that both goals and self-efficacy influence directly and independently on performance. Self-efficacy can also influence performance indirectly through influencing personal goal choice and commitment to goals. In the end, setting goals influences self-efficacy in this way: in view of the fact that setting challenging goals equates with showing a sense of confidence, those who assign high goals are more likely to enjoy high self-efficacy as compared to those selecting low goals (Bandura, 1986, 1988; Locke \& Latham, 1990).

In 1995, Mone, Baker, and Jeffries found academic self-efficacy as an important predictor of personal academic goal-setting and academic performance. They maintained that a student's academic goal-setting and academic performance could get better by dint of effectively enhancing his academic self-efficacy. Likewise, Chemers et al. (2001) found a strong association between academic expectations and academic achievement. In a similar vein, in 2002, Locke and Latham exhibited that goal-setting was significantly related to self-efficacy beliefs.

\subsection{Significance of the Study}

As we know, goals or objectives are of prime importance in educational contexts since they are considered as underlying reasons for motivation (Wiggins \& McTighe, 2000). Goals are fundamental elements of motivation and learning (Schunk, 2003). Moreover, according to Bandura's (1982) self-efficacy theory, efficacy is the key contributing factor of effort, persistence, and goal-setting. Therefore, the operation of goals proceeds to be a fundamental and dominant topic in motivation theory and the importance of them and their interaction with self-efficacy and performance is highly considerable (Bandura, 1986; Locke, Motowidlo, \& Bobko, 1986). 
The role of goal-setting theory on Iranian EFL learners' motivation and self-efficacy

However, not much published research is available to show the influence of goal-setting theory on Iranian EFL learners' motivation and self-efficacy. The necessity for such a study is seriously felt when one realizes that such study can provide the experts in the field of language teaching with information about the pivotal role of goal-setting theory in learners' perceived capabilities and their subsequent motivation and involvement in learning. In other words, such a study is a rewarding area of research for broadening the language learners and teachers' understanding of how choice of goals can affect efficacy beliefs and motivation of the students. Accordingly, the present study is a partial attempt to fill this gap. More precisely, this study aims to focus particularly on the role of goal choices on Iranian EFL students' efficacy beliefs and motivation. Therefore, the following research question is posed:

$>$ Does Iranian EFL learners' goal choice play any significant role in their self-efficacy and motivation?

\section{Method}

\subsection{Participants}

The participants of this study consisted of 93 EFL students (38 males and 55 females) from Ferdowsi, Khayyam, and Imam Reza universities in Mashhad, Iran. 38 students were MA level learners and 55 students were in BA level. It should be noted that all the students who took part in this study majored in the various branches of English, such as Teaching English as a Foreign Language, English Literature, or English Translation.

\subsection{Instrumentation}

To measure the motivation and self-efficacy of the learners, three instruments were employed: General Self-efficacy Scale, English Self-efficacy Scale, and Motivation Scale. In order to measure the General self-efficacy of the participants, the scale which was developed and validated by Sherer et al. (1982) was used. This scale includes 17 items. Each item recipes a score of 1 to 5 producing a score range of 17 to 85 . In the current study, Cronbach's alpha for this scale was 0.89. In order to assess learners' English self-efficacy, the scale developed and validated by Rahemi (2007) was utilized. This scale consisted of 10 five point Likert scale ranging from 'strongly disagree' (one) to 'strongly agree' (five). The total reliability of the scale in the current study, estimated via Cronbach’s alpha, was 0.83 .

To measure students' motivation, the researchers used Language Learning Orientations Scale (LLOS) developed and validated by Noels, Pelletier, Clément, and Vallerand (2000). It comprises 21 seven point Likert-scale in three sections measuring three subcomponents of intrinsic, extrinsic motivation, and amotivation. The first section contains scale to assess amotivation (alpha $=.81$ ) which is composed of three items. The second section contains nine items to measure three types of EM, including external, introjected, and identified regulation (alpha $=.85$ ). And the last one contains nine items indexing three types of $I M$, including knowledge, mastery, and stimulation (alpha = .86). It is worthy to mention that the Persian version of the instrument, which was translated into Persian and validated by Khodadady and Khajavi (2013), was utilized in this study.

\subsection{Procedure}

The students' goal choice was measured by dint of essay writing examination. Passing the writing course in advance was the prerequisite for the students to participate in this study and to be assessed with essay examination. Two possible composition topics and three goal choices (A, B and C) were presented to students one week prior to the exam day. The students were presented with the choice to pick one of the goals $(\mathrm{A}, \mathrm{B}$, or $\mathrm{C})$ and prepare themselves for the exam. The A level was designed as a six-paragraph essay along with six references. The $\mathrm{B}$ level was a five-paragraph essay accompanied with five references, and the $\mathrm{C}$ level was defined as a four-paragraph essay with four references. 
Hosseini, F. A., Pishghadam, R., \& Vahidnia, F.

Each goal required progressively longer and more challenging compositions with more research and preparation effort, thus the goals were resource-based. As the preparation time for the exam was limited and the requirements for the task were presented in detail, the goal-setting was proximal and time limited and the goals were specific and measurable. Therefore, this goal-setting model clearly ensued the basic requirements of goal-setting theory.

It is noteworthy that one extra score and ten presents allocated to the participants of this project; the teachers gave some extra scores to all those students taking part in and the first ten best writers were rewarded by presents. Higher grades directly corresponded to the participants' goal choices and the quality of their writing. A week later and prior to essay examination, the candidates were asked to fill out the questionnaires then the researchers selected one of the topics to be written about in the same session.

\section{Result}

To address the research question MANOVA was applied. The descriptive statistics for the dependent variables in terms of goal choice is provided in Table1.

\section{Table 1}

Descriptive Statistics: Goal Choice in English, General Self-Efficacy, and Motivation Subscales

\begin{tabular}{lccrc}
\hline & Goal choice & Mean & Std. deviation & $\mathrm{N}$ \\
\hline General self-efficacy & $\mathrm{A}$ & 67.4390 & 9.15710 & 41 \\
& $\mathrm{~B}$ & 62.1875 & 11.60585 & 16 \\
& $\mathrm{C}$ & 57.4167 & 8.42573 & 36 \\
& Total & 62.6559 & 10.31514 & 93 \\
\hline English self-efficacy & $\mathrm{A}$ & 44.7317 & 5.15279 & 41 \\
& $\mathrm{~B}$ & 40.0000 & 4.96655 & 16 \\
& $\mathrm{C}$ & 37.5556 & 5.47954 & 36 \\
& Total & 41.1398 & 6.16369 & 93 \\
\hline Extrinsic motivation & $\mathrm{A}$ & 40.4146 & 7.55306 & 41 \\
& $\mathrm{~B}$ & 40.8125 & 8.57297 & 16 \\
& $\mathrm{C}$ & 35.7778 & 7.97894 & 36 \\
& Total & 38.6882 & 8.15072 & 93 \\
\hline Intrinsic motivation & $\mathrm{A}$ & 48.4375 & 11.41656 & 41 \\
& $\mathrm{~B}$ & 47.6341 & 10.72672 & 16 \\
& $\mathrm{C}$ & 46.8333 & 9.28747 & 36 \\
& Total & 47.4624 & 10.42005 & 93 \\
\hline Amotivation & $\mathrm{A}$ & 3.8780 & 2.44126 & 41 \\
& $\mathrm{~B}$ & 4.2500 & 2.32379 & 16 \\
& $\mathrm{C}$ & 5.3056 & 3.21443 & 36 \\
& Total & 4.4946 & 2.79994 & 93 \\
\hline
\end{tabular}

A brief inspection of Table 1 points out that the mean score for the A group, members of which selected the challenging goal, in General and English self-efficacy and intrinsic motivation were more than the other two groups. In General self-efficacy, group ' $A$ ' was the most successful one $(X '=67.43)$ which indicates their higher scores in General self-efficacy. Group 'B', the members of which enjoyed the moderately difficult goal, ranked second in General self-efficacy (mean $=62.18$ ), and the group ' $C$ ', members of which favored an easy goal, had the lowest ranking in General self-efficacy (mean $=57.41$ ). More specifically, those students who preferred more challenging goal reported significantly higher General self-efficacy when compared to both the ' $\mathrm{B}$ ', and ' $\mathrm{C}$ ' groups. In this vein, learners who preferred the hard goal also showed the best mean score in English self-efficacy $\left(X^{\prime}=44.73\right)$. Group 'B' ranked second in English self-efficacy (mean $\left.=40\right)$, and the group ' $C$ ' was located in the lowest ranking concerning English self-efficacy (mean $=37.55$ ). To put it differently, those students who opted for the high goal felt more capable and confident about their capabilities than others, so their self-efficacy was higher than those students who chose a moderately difficult or an easy goal. 
The role of goal-setting theory on Iranian EFL learners' motivation and self-efficacy

Overall, those learners who expended greater effort and persisted longer than students who doubted their capabilities were apt for choosing challenging goals. However, those students who held low self-efficacy for learning avoided demanding tasks and selected the easy ones. This would mean that learners who felt confident about solving a problem and attributed their success mainly to their own efforts and strategies, believed that their own abilities would improve as they learnt (Rahemi, 2007), tended more to set higher goals. Whereas, those learners who doubted their capabilities set easily achievable goals.

In intrinsic motivation, group ' $A$ ' had the highest level of intrinsic motivation (mean = 48.73). Group ' $B$ ' was in the middle regarding intrinsic motivation (mean $=47.63$ ), and group ' $C$ ' showed the lowest intrinsic motivation (mean $=46.83$ ). This means that those learners who had the desire to take part in an activity purely for the sake of participating in and completing the activity tended to opt for the challenging goals. In comparison, group ' $\mathrm{B}$ ' exhibited the highest level of extrinsic motivation (mean = 40.81). Group 'A' was in between concerning extrinsic motivation (mean $=40.41$ ), and group ' $\mathrm{C}$ ' had the lowest ranking in extrinsic motivation (mean $=35.77$ ). This means that those students who belonged to group ' $\mathrm{B}$ ' were more extrinsically motivated as opposed to group 'A'. That is, those students who engaged in an activity to attain rewards, such as praise and grades were more likely to pick moderately difficult goal. At last, in amotivation, group ' $\mathrm{C}$ ', the members of which preferred to choose the easy goal, showed the highest level of amotivation (mean $=5.30$ ). In other words, the more amotivated a student was; the easier goal he chose. Group 'B' which showed lower amotivation as compared to group ' $C$ ', located in the second position regarding amotivation (mean $=4.25$ ). Interestingly, group ' $A$ ' had the lowest ranking in amotivation (mean =3.87); those students picking challenging goals were apt to be less amotivated. To put it differently, those Iranian EFL learners who had no reason to do an activity pursued the easy goal, instead; those who had either extrinsic or intrinsic motivation for engaging in an activity opted for the challenging or moderately difficult goal.

The actual result of the one-way MANOVA can be found in the Multivariate Tests Table represented below. Table 2 reports the result of Multivariate Tests.

Table 2

Multivariate Results for the Significance of Differences among the Means of Variables

\begin{tabular}{llllll}
\hline Effect & & Value & F & Sig. & Partial eta $^{2}$ \\
\hline \multirow{4}{*}{ Level } & Pillai'sTrace & .410 & 4.492 & .000 & .205 \\
\cline { 2 - 6 } & Wilks' Lambda & .600 & 5.000 & .000 & .225 \\
\cline { 2 - 6 } & Hotelling's Trace & .6485 & .510 & .000 & .245 \\
\cline { 2 - 6 } & Roy's Largest Root & .620 & 10.780 & .000 & .383 \\
\hline
\end{tabular}

Examining the table revealed that goal choice did exert a significant effect on students' motivation, English and General self-efficacy. That is, there was a statistically significant difference between students' goal choices regarding their extrinsic and intrinsic motivation, amotivation, English and General self-efficacy $(\mathrm{F}=5.000, \mathrm{P}$ $<.05$; Wilk's $\lambda=.600$ ). To ascertain the effects of goal choice on each of the different DVs, another table named univariate ANOVAs was created. Table 3 presents the results of five separate univariate ANOVAs.

Table 3

Goal Choice by DVs

\begin{tabular}{llccccc}
\hline Source & Dependent variable & $\begin{array}{c}\text { Type III sum of } \\
\text { squares }\end{array}$ & Df & Mean square & F & Sig. \\
\hline \multirow{4}{*}{ Goal choice } & General self-efficacy & 1929.704 & 2 & 964.852 & 11.049 & .000 \\
\cline { 2 - 7 } & English self-efficacy & 1012.245 & 2 & 506.123 & 18.346 & .000 \\
\cline { 2 - 7 } & Intrinsic & 499.346 & 2 & 249.673 & 4.004 & .022 \\
\cline { 2 - 7 } & Extrinsic & 30.669 & 2 & 15.334 & .139 & .871 \\
\cline { 2 - 7 } & Amotivation & 40.218 & 2 & 20.109 & 2.657 & .076 \\
\hline
\end{tabular}


According to Table 3, goal choice exerted a significant effect on the results of intrinsic motivation $(\mathrm{p}=.022)$, English self-efficacy $(\mathrm{p}=.000)$, and General self-efficacy $(\mathrm{p}=.000)$. As such, the results demonstrated that there was a significant difference among goal choices with regard to English self-efficacy $(F=18.34, p<.05$ ), intrinsic motivation $(\mathrm{F}=4.00, \mathrm{p}<.05)$, and General self-efficacy $(\mathrm{F}=11.04, \mathrm{p}<.05)$. Alternatively, the findings revealed that goal choice did not have a significant effect on the results of extrinsic motivation and amotivation.

To conclude, goal choice differences indicated that those EFL Iranian students who reported higher intrinsic motivation, higher English and General self-efficacy showed great tendency to pick the challenging goal. That is, students' English and General self-efficacy affected the kind of goals they selected. With regard to intrinsic motivation, students' intrinsic motivation influenced the kind of goals they set; the higher intrinsic motivation a student had, the higher the probability of picking the hard goal would exist.

\section{Discussion}

The general goal put forward by this study was to explore the role of students' choice of goals in their motivation and self-efficacy. With regard to the role of goal choice in students' self-efficacy and according to the presented findings, those students who favored more challenging goal reported significantly higher General self-efficacy as compared to those who picked moderate or the least difficult goal. In this vein, learners with high English self-efficacy selected the most difficult goal compared with other students. Put another way, learners who opted for the high goal judged themselves to be more capable and confident about their capabilities than others; therefore, their self-efficacy were higher than those learners who attempted a moderate or an undemanding goal. Hence, the significant point to be considered is the salient role of self-efficacy in goal-setting theory (Locke \& Latham, 2002).

All in all, Iranian EFL learners who exerted greater effort and exhibited longer persistence than students who suspected of their capabilities, showed more willingness to select challenging goals. This is in line with Bandura's contention that self-efficacious students embark on difficult and challenging tasks than do inefficacious students (1993). However, as Bandura (1986) and Seifert (2004) maintained, individuals who enjoyed low self-efficacy for learning avoided difficult tasks and selected the easy ones. This brings us to the issue previously discussed by Rahemi (2007) that learners who believe in their capabilities in solving a problem and attribute their success largely to their own efforts and strategies, are more apt for setting higher goals.

The findings of the present study also support the following studies which suggest that self-efficacy exerts a powerful effect on students' task persistence, task interest, the choices they make and the goals they set (Lent et al., 2002; Linnenbrink \& Pintrich, 2003; Schunk, 2003; Zimmerman et al., 1992). Furthermore, there is evidence that the more efficacious students are more likely to welcome the more challenging goals (Zimmerman et al., 1992). Likewise, the result is consistent with sociocognitive theory which demonstrates that high self-efficacy can encourage individuals to embrace higher levels of goals over time (Locke \& Latham, 1990). In addition, this study offers further support for Bandura's argument (1993) that individuals with high self-efficacy tend to pick difficult (high) goals than those with low self-efficacy.

A salient issue to be discussed is the idea of perceived self-efficacy. It is crystal clear that when a student is highly confident in his capability in a particular task, he will be more inclined to undertake a task which he believes he can succeed. Therefore, when the same student wants to set a goal for himself, he embraces the more challenging goal. On the other hand, a learner who perceives himself as incapable in performing a task will attempt the more easy ones; he does not attempt to attain what he believes is impossible. As a result, students with low self-efficacy are unlikely to pursue goals beyond their perceived capability. Therefore, students consider not just what they want when setting goals, but what they think they can attain.

The last justification is that striving for high goals has costs with regard to effort, time, persistence and other values. Students with high self-efficacy devote more time, exert more effort, and exhibit more persistence in reaching their high goals. Thus, the reason behind preferring the challenging goal among students having high 
The role of goal-setting theory on Iranian EFL learners' motivation and self-efficacy

self-efficacy in this study was possibly due to this fact. Conversely, when students having low self-efficacy believe a task is harder than it actually is, their effort and persistence will be reduced. On account of not being inclined to expend more effort, devote more time, and persist, learners holding low self-efficacy in this study preferred not to select the most difficult goal.

Regarding the role of goal choice in students' motivation and based on the presented results, it can be deduced that goal choice showed a significant effect on students' motivation. This finding lends support to abundant research which attests to the effectiveness of goals in enhancing students' motivation (Bandura, 1988; Locke \& Latham, 1990).

In summary, when Iranian EFL learners found no reason for carrying out an activity, they attempted the easy goal, conversely; when they were either extrinsically or intrinsically motivated, they favored to pick the challenging or moderate goal. As evidence for this claim is the contention that intrinsic and extrinsic motivation as keystone constructs underlie goal theory of motivation (Elliot, 1999; Meece, Anderman, \& Anderman, 2006). Respecting amotivation, the obtained result substantiates Lee, Sheldon, and Turban s' arguments that an "amotivated" orientation is related to goal-avoidance motivation which is in turn accompanied by lower goal levels (2003).

In view of the literature, there seems to be a clear connection between mastery goals (task goals) and intrinsic motivation and performance goals and extrinsic motivation (Lepper, Henderlong, Carol, \& Judith, 2000). As task-goal oriented students tend to choose challenging tasks for themselves (Elliot, 1999; Pintrich, 2000a, 2000b), intrinsically students of the current study opted for the challenging goal. More to the point, performance-goal-oriented learners tend to avoid tasks where others may judge them unfavorably because of possible errors they may make. Therefore, they prefer to select moderate or easy tasks in which they can look good in the eyes of others (Elliot, 1999; Pintrich, 2000a). Extrinsically motivated learners of this research favored moderate goal. This finding confirms those of Elliot (1999) and Pintrich (2000a).

The aforementioned results might be attributed to a number of factors. First, as intrinsic motivation derives from intrinsic motivators of challenge, curiosity, and control (Deci \& Ryan, 1985), intrinsically motivated participants might get curious to try and conquer challenges which they could find just in pursuing the high goal. Second reason for such choice was perhaps due to their desire to master the task and experience new things while knowing that mastering a task needs exercising much effort and devoting much time. Accordingly, maybe they thought that the choice of challenging goal could help them in doing so. Another explanation for their choice may depend on their faith in their capabilities to perform the task and their persistence in the face of difficulty. Finally, maybe they assumed that by picking challenging goal they could seek out opportunities to develop their competencies.

On the other hand, extrinsically motivated learners preferred the moderate goal. This might be related to this assertion that extrinsically motivated students tend to prove their competence and they wish to compare themselves with others (Miller et al., 1998). Because of this characteristic they avoid failures to not being judged unfavorably by others due to possible errors they might make. Hence, the participants of this study did not pick challenging goal because maybe they had fear of failure and thought that they could not pursue this goal when faced with difficulty. As a result, they selected moderate goal in which they could look good in the eyes of others.

With respect to amotivated students, a possible justification for their choice of easy goal might be due to not expecting any external reward such as prize to do a task or not being interested in doing the task itself. Another significant point to be considered is that they might think that by picking the easy goal, they would not need to exert much effort and devote their time since they did not have the desire to do so. As participants of this research were supposed to receive extra score provided that they took part in the project, the amotivated students perhaps wanted to participate in the project solely for the sake of extra score which they needed, not for taking part in the writing competition which were expected to have ten winners who had the highest scores relative to 
Hosseini, F. A., Pishghadam, R., \& Vahidnia, F.

their choices and their quality of their writing. Accordingly, they did not become motivated to write well and choose a moderate or difficult goal; instead, they preferred to pursue the easy goal.

\section{Conclusion}

As already mentioned, in this study we tried to examine the effect of Iranian EFL learners' choice of goals on their efficacy beliefs and motivation. Overall, the outcomes of this study revealed that high efficacious students tended to embark on difficult goal as opposed to low efficacious students. Additionally, intrinsically motivated learners opted for the difficult goal, extrinsically motivated students selected the moderate one, and amotivated learners picked the easy one.

All things considered, the finding of this study carries some considerable implications. First and foremost, the findings of this study are indicative of the plausibility of the application of goal-setting theory and its profound impact on motivation and self-efficacy pedagogy. EFL/ESL practitioners could, thus, incorporate this theory of motivation in their instruction so as to enhance the self-efficacy and motivation of learners. Second, the findings of the study can be of interest to EFL learners, in that they get to know the ways in which they can raise their own efficacy beliefs and have a substantial role in motivating themselves. They can also increase the quality of their learning by knowing how to set goals properly.

Considering that language learning is a multidimensional phenomenon, not only are language learners, but also language teachers and material developers, required to play their roles properly in order for language learning to be facilitated and optimized. Therefore, teachers should be helped to realize the importance of efficacy beliefs, motivation, and goal-setting theory and the role they have in student learning so that they can convey this importance to EFL students. Hence, teachers are expected to be acquainted with the factors affecting students' motivation and self-efficacy, striving hard to increase the students' learning through boosting their motivation and their sense of self-efficacy. In doing so, teachers can design some other activities and tasks to spur students to pick challenging, realistic and specific goals. Moreover, based on the results of the current research, teachers can rely on the goal-setting theory as an effective strategy to identify self-efficacious and motivated students in classrooms. Furthermore, through comparing the results of this study with other similar studies, it is possible to figure out whether there is a universal pattern in picking the goal by students or not. To boot, the findings of the study might be fruitful for material developers to design new textbooks and other educational materials with exercises and activities truly addressing the goal choice, motivation, and efficacy beliefs of text users. In conclusion, the present study takes a great step in our understanding of the effect of goal-setting theory on learners' motivation and self-efficacy.

Due to lack of access to other universities in Iran, it was not possible for the researchers to compare university students of Mashhad with other students in different cities as well. Therefore, it is thoroughly recommended that further research be carried out in this realm. In addition, this study did not take learners' gender and educational level as variables into account, so future studies can shed light on the influence of these variables. Our findings can also be compared with those of other settings and cultures to come up with cross cultural understanding. Since, our community of sample is not representative of the population of English language learners of neither Mashhad nor Iran, generalization is not recommended.

\section{References}

Bandura, A. (1977). Self-efficacy: Toward a unifying theory of behavioral change. Psychological Review, 84, 191-215. http://dx.doi.org/10.1037/0033-295X.84.2.191

Bandura, A. (1982). Self-efficacy mechanism in human agency. American Psychologist, 37(2), 122-147. http://dx.doi.org/10.1037/0003-066X.37.2.122

Bandura, A. (1986). Social foundations of thought and action: A social cognitive theory. Englewood Cliffs, NJ: Prentice-Hall. 
The role of goal-setting theory on Iranian EFL learners' motivation and self-efficacy

Bandura, A. (1988). Self-regulation of motivation and action through goal systems. In V Hamilton, G. H. Bower, $\&$ N. H. Frijda (Eds.), Cognitive perspectives on emotion and motivation (pp. 37-61). Dordrecht, The Netherlands: Kluwer Academic Publishers. http://dx.doi.org/10.1007/978-94-009-2792-6_2

Bandura, A. (1993). Perceived self-efficacy in cognitive development and functioning. Educational Psychologist, 28(2), 117-148. http://dx.doi.org/10.1207/s15326985ep2802_3

Bandura, A., \& Cervone, D. (1986). Differential engagement of self-reactive influences in cognitive motivation. Organizational Behavior and Human Decision Processing, 38, 92-113. http://dx.doi.org/10.1016/0749-5978(86)90028-2

Bandura, A., \& Locke, E. A. (2003). Negative self-efficacy and goal effect revisited. Journal of Applied Psychology, 88, 87-99. http://dx.doi.org/10.1037/0021-9010.88.1.87

Chemers, M. M., Hu, L. T., \& Garcia, B. F. (2001). Academic self-efficacy and first-year college student performance and adjustment. Journal of Educational Psychology, 93(1), 55-64. http://dx.doi.org/10.1037/0022-0663.93.1.55

Datu, J. A. (2013). Be happy and believe in your capacity: Establishing link between subjective well-being and self-efficacy among Filipino adolescents. International Journal of Research Studies in Psychology, 2, 1-8. http://dx.doi.org/10.5861/ijrsp.2012.206

Deci, E. L., \& Ryan, R. M. (1985). Intrinsic motivation and self-determination in human behaviour. New York: Plenum. http://dx.doi.org/10.1007/978-1-4899-2271-7

Dweck, C. S. (1998). The development of early self-conceptions: Their relevance for motivational processes. In J. Heckhausen \& C. S. Dweck (Eds.), Motivation and self-regulation across the life span (pp. 257-280). New York: Cambridge University Press. http://dx.doi.org/10.1017/CBO9780511527869.012

Elliot, A. (1999). Approach and avoidance motivation and achievement goals. Educational Psychologist, 34(3), 169-189. http://dx.doi.org/10.1207/s15326985ep3403_3

Eslami, R. Z., \& Fatahi, A. (2008). Teachers' sense of self- efficacy, English proficiency, and instructional strategies: A study of nonnative EFL teachers in Iran. TESL-EJ Journal, 11(4), 1-19.

Ghonsooly, B., Elahi, M., \& Golparvar, S. E. (2012). General English university students' self- efficacy and their achievement. The Iranian EFL Journal, 8(3), 153-173.

Heidari, F., Izadi, M., \& Vahed Ahmadian, M. (2012). The relationship between Iranian EFL learners' self-efficacy beliefs and use of vocabulary learning strategies. English Language Teaching, 5(2), 174-182. http://dx.doi.org/10.5539/elt.v5n2p174

Hosseini Fatemi, A., \& Vahidnia, F. (2013). Self-efficacy and motivation among Iranian EFL learners: An investigation into their relationships. International Journal of English Language Education, 1(3), 79-89. http://dx.doi.org/10.5296/ijele.v1i3.3771

Khodadady, E., \& Khajavy, G. H. (2013). Exploring the role of anxiety and motivation in foreign language achievement: A structural equation modeling approach. Porta Linguarum, 20, 269-286.

Lee, F. K., Sheldon, K. M., \& Turban, D. (2003). Personality and the goal striving process: The influence of achievement goal patterns, goal level, and mental focus on performance and enjoyment. Journal of Applied Psychology, 88(2), 256-265. http://dx.doi.org/10.1037/0021-9010.88.2.256

Lent, R. W., Brown, S. D., \& Hackett, G. (2002). Social cognitive career theory. In D. Brown (Ed.), Career choice and development (pp. 255-311). San Francisco: Jossey-Bass.

Lepper, M. R., Henderlong, J., Carol, S., \& Judith, M. H. (2000). Turning “play” into "work” and "work” into "play": 25 Years of research on intrinsic versus extrinsic motivation. In C. Sansone \& J. Harackiewicz (Eds.), Intrinsic and extrinsic motivation (pp. 257-307). San Diego: Academic Press. http://dx.doi.org/10.1016/B978-012619070-0/50032-5

Linnenbrink, E. A., \& Pintrich, P. R. (2003). The role of self-efficacy beliefs in student engagement and learning in the classroom. Reading and Writing Quarterly: Overcoming Learning Difficulties, 19(2), 119-138. http://dx.doi.org/10.1080/10573560308223

Locke, E. A., \& Latham, G. P. (1990). A theory of goal setting and task performance. Englewood Cliffs, NJ: Prentice-Hall.

Locke, E. A., \& Latham, G. P. (2002). Building a practically useful theory of goal setting and task motivation: A 
Hosseini, F. A., Pishghadam, R., \& Vahidnia, F.

35-year odyssey. American Psychologist, 57(9), 705-717.

http://dx.doi.org/10.1037/0003-066X.57.9.705

Locke, E. A., Motowidlo, S. J., \& Bobko, P. (1986). Using self-efficacy theory to resolve the conflict between goal-setting theory and expectancy theory in organizational behavior and industrial/ organizational psychology. Journal of Social and Clinical Psychology, 4, 328-338. http://dx.doi.org/10.1521/jscp.1986.4.3.328

Locke, E. A., Shaw, K. N., Saari, L. M., \& Latham, G. P. (1981). Goal setting and task performance: 1969-1980. Psychological Bulletin, 90, 125-152. http://dx.doi.org/10.1037/0033-2909.90.1.125

Maehr, M. L., \& Midgley, C. (1991). Enhancing student motivation: A school wide approach. Educational Psychologist, 26, 399-427.

Maehr, M. L., \& Zusho, A. (2009). Achievement goal theory: The past, present, and future. In K. R. Wentzel \& A. Wigfield (Eds.), Handbook of motivation in school (pp. 77-104). New York: Taylor Francis.

Meece, J. L., Anderman, E. M., \& Anderman, L. H. (2006). Classroom goal structure, student motivation, and academic achievement. Annual Review Psychology, 57, 487-503. http://dx.doi.org/10.1146/annurev.psych.56.091103.070258

Miller, A., Ferguson, F., \& Simpson, R. (1998). The perceived effectiveness of rewards and sanctions in primary schools: Adding in the parental perspective. Educational Psychology, 18, 55-64. http://dx.doi.org/10.1080/0144341980180104

Mills, N., Pajares, F., \& Herron, C. (2006). A reevaluation of the role of anxiety: Self- efficacy, anxiety, and their relation to reading an listening proficiency. Foreign Language Annals, 39(2), 273-292. http://dx.doi.org/10.1111/j.1944-9720.2006.tb02266.x

Mone, M. A., Baker, D. D., \& Jeffries, F. (1995). Predictive validity and time dependency of self-efficacy, self-esteem, personal goals, and academic performance. Educational Psychological Measurement, 55, 716-727. http://dx.doi.org/10.1177/0013164495055005002

Naseri, M., \& Zaferanieh, E. (2012). The relationship between reading self-efficacy beliefs, reading strategy use and reading comprehension level of Iranian EFL learners. World Journal of Education, 2(2), 64-75. http://dx.doi.org/10.5430/wje.v2n2p64

Noels, K. A. (2001). Learning Spanish as a second language: Learners' orientations and perceptions of their teachers' communication style. Language Learning, 51(1), 107-144. http://dx.doi.org/10.1111/0023-8333.00149

Noels, K. A., Pelletier, L. G., Clément, R., \& Vallerand, R. J. (2000). Why are you learning second language? Motivational orientations and self-determination theory. Language Learning, 50, 57-85. http://dx.doi.org/10.1111/0023-8333.00111

Pajares, F. (2002).Overview of social cognitive theory and of self-efficacy. Retrieved March 11, 2010, from http://www.emory.edu/EDUCATION/mfp/eff.html

Pintrich, P. R. (2000a). The role of goal orientation in self-regulated learning. In M. Boekaerts, P. R. Pintrich \& M. Zeidner (Eds.), Handbook of self-regulation (pp. 451-501). San Diego, CA: Academic Press. http://dx.doi.org/10.1016/B978-012109890-2/50043-3

Pintrich, P. R. (2000b). Multiple goals, multiple pathways: The role of goal orientation in learning and achievement. Journal of Educational Psychology, 92, 544-555. http://dx.doi.org/10.1037/0022-0663.92.3.544

Pintrich, P. R. (2000c). An achievement goal theory perspective on issues in motivation terminology, theory, and research. Contemporary Educational Psychology, 25(1), 92-104. http://dx.doi.org/10.1006/ceps.1999.1017

Pintrich, P. R., \& Schunk, D. H. (1996). Motivation in education: Theory, research and Applications. Englewood Cliffs, NJ: Merrill Company.

Pintrich, P. R., \& Schunk, D. H. (2002). Motivation in education: Theory, research, and Applications ( $2^{\text {nd }}$ ed). Englewood Cliffs, NJ: Prentice Hall.

Rahemi, J. (2007). Self-efficacy in English and Iranian senior high school students majoring in humanities. Novitas-ROYAL, 1(2), 98-111. 
The role of goal-setting theory on Iranian EFL learners' motivation and self-efficacy

Rahimi, A., \& Abedini, A. (2009). The interface between EFL learners' self- efficacy concerning listening comprehension and listening proficiency. Novitas Royal, 3(1), 14-28.

Rahimpour, M., \& Nariman-jahan, R. (2010). The influence of self-efficacy and proficiency on EFL learners' writing. Journal of Instructional Technology and Distance Learning, 7(11), 23-36.

Ryan, R. M., \& Deci, E. L. (2000a). Intrinsic and extrinsic motivations: Classic definitions and new directions. Contemporary Educational Psychology, 25, 54-67. http://dx.doi.org/10.1006/ceps.1999.1020

Ryan, R. M., \& Deci, E. L. (2000b). Self-determination theory and the facilitation of intrinsic motivation, social development, and wellbeing. American Psychologist, 55(1), 68-78. http://dx.doi.org/10.1037/0003-066X.55.1.68

Schmidt, R., Boraie, D., \& Kassabgy, O. (1996). Foreign language motivation: Internal structure and external connections. In R. L. Oxford (Ed.), Language learning motivation: Pathways to the new century (pp. 14-87). Honolulu, HI: The University of Honolulu Press.

Schunk, D. H. (2003). Self-efficacy for reading and writing: Influence of modeling, goal setting and self-evaluation. Reading and Writing Quarterly: Overcoming Learning Difficulties, 19(2), 159-172. http://dx.doi.org/10.1080/10573560308219

Seifert, T. L. (2004). Understanding student motivation. Educational Research, 46(2), 137-149. http://dx.doi.org/10.1080/0013188042000222421

Sherer, M., Maddux, J. E., Mercandante, B., Prentice-Dunn, S., Jacobs, B., \& Rogers, R. W. (1982). The self-efficacy scale: Construction and validation. Psychological Reports, 51, 663-671. http://dx.doi.org/10.2466/pr0.1982.51.2.663

Vancouver, J. B., Thompson, C. M., \& Williams, A. A. (2001). The changing signs in the relationships among self-efficacy, personal goals, and performance. Journal of Applied Psychology, 86, 605-620. http://dx.doi.org/10.1037/0021-9010.86.4.605

Vansteenkiste, M., Lens, W., \& Deci, E. L. (2006). Intrinsic versus extrinsic goal contents in self-determination theory: Another look at the quality of academic motivation. Educational Psychologist, 41(1), 19-31. http://dx.doi.org/10.1207/s15326985ep4101_4

Webb-Williams, J. (2006). Self-efficacy in the primary classroom: An investigation into the relationship with performance. Paper presented at the meeting of the British Educational Research Association New Researchers/Student Conference, University of Warwick, Britain.

Wiggins, G., \& McTighe, J. (2000). Understanding by design. New Jersey: Prentice Hall.

William, M., \& Burden, R. L. (1997). Psychology for language teachers: A social constructivist approach. Cambridge, U.K.: Cambridge University Press.

Zare, M., \& Davoudi Mobarakeh, S. (2011). The relationship between self-efficacy and use of reading strategies: The case of Iranian senior high school students. Studies in Literature and Language, 3(3), 98-105.

Zimmerman, B. J., Bandura, A., \& Martinez-Pons, M. (1992). Self-motivation for academic attainment: The role of self-efficacy beliefs and personal goal setting. American Educational Journal, 29(3), 663- 676. http://dx.doi.org/10.3102/00028312029003663 


\section{Appendix A}

\section{General Self efficacy Scale}

Full name:

Contact no.

Email :

Degree:
PHD
Major:

Age:

Gender:

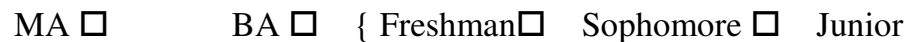

Senior $\square\}$

Instructions: This questionnaire is a series of statements about your personal attitudes and traits. Each statement represents a commonly held belief. Read each statement and decide to what extent it describes you. There are no right or wrong answers. You will probably agree with some of the statements and disagree with others. Please indicate your own personal feelings about each statement below by marking the letter that best describes your attitude or feeling. Please be very truthful and describe yourself as you really are, not as you would like to be.

Mark: A If you Disagree Strongly with the statement

C If you Neither Agree nor Disagree

B If you Disagree Moderately

E If you Agree Strongly with the statement

\section{If you Agree Moderately}

1. When I make plans, I am certain I can make them work.

$\frac{\text { Strongly disagree }}{\text { A }} \quad \frac{\text { disagree moderately }}{\text { B }} \quad \frac{\text { neutral }}{\mathrm{C}} \quad \frac{\text { agree moderately }}{D} \quad \frac{\text { strongly }}{\mathrm{E}}$

2. One of my problems is that I cannot get down to work when I should.
A
B
C
D
E

3. If I can't do a job the first time, I keep trying until I can.
A
B
C
D
E

4. When I set important goals for myself, I rarely achieve them.
A
B
C
D
E

5. I give up on things before completing them.
A
B
C
$\mathrm{D}$
$\mathrm{E}$

6. I avoid facing difficulties

A B C

C D

E

7. If something looks too complicated, I will not even bother to try it.
A
B C
C D
E

8. When I have something unpleasant to do, I stick with it until I finish it.
A
B
C
D
E

9. When I decide to do something, I go right to work on it.
A
B
C
D
E

10. When trying to learn something new, I soon give up if I am not initially successful.
A
B
C
D
E

11. When unexpected problems occur, I don't handle them well.
A
B
$\mathrm{C}$
$\mathrm{D}$
$\mathrm{E}$

12. I avoid trying to learn new things when they look too difficult to me.
A
B
C
D
E

13. Failure just makes me try harder.
A
B C
$\mathrm{D}$
$\mathrm{E}$

14. I feel insecure about my ability to do things.
A
B
C
D
E

15. I am a self-reliant person.
A B
C
D
$\mathrm{E}$

16. I give up easily.

$\begin{array}{ccc}\text { A } & \text { B } & \text { C } \\ \text { 17. I do not seem capable of dealing with most problems that come up in my life. }\end{array}$
A
B
C
D
E

E 


\section{Appendix B}

\section{English Self efficacy}

Full name:

Contact no,
Email adress:

Major:

Age:

Gender: $\quad$ Male $\square \quad$ Female $\square$

Degree: $\quad$ PHD

MA $\square$

BA $\square \quad$ \{ Freshman $\square$ Sophomore

Junior $\square \quad$ Senior

Dear student:

Below are beliefs and feelings that some people have about learning foreign languages. Read the statement and then decide if you: (5) strongly agree, (4) agree, (3) neither agree nor disagree, (2) disagree , (1) strongly disagree.

There are no right or wrong answers.

1. I have got a special ability for learning English.

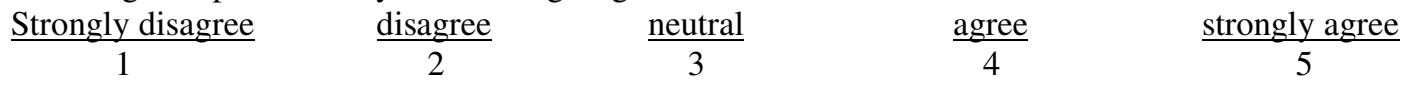

2. I believe I have the power to get my desired grade in English final exam.

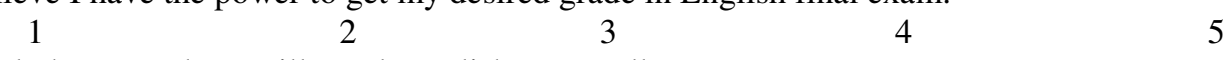

3. I think that someday I will speak English very well.
$1 \quad 2 \quad 3$

$\begin{array}{ccccc}1 & 2 & 3 & 4 & 5 \\ \text { 4. I am sure I can solve any problems I face in learning English because I've got the power to do }\end{array}$ 5 $1 \quad 20435$

5. Personally, I'm satisfied with my current level of English proficiency.

$\begin{array}{lllll}1 & 2 & 3 & 4 & 5\end{array}$

6. I'm definitely sure that I can improve my English by trying more.
1
2
3
4
5

7. If I do not do well in this lesson, it is only because I do not exert enough effort.
1
2
3

4
5

8. Generally speaking, myself -confidence in English classes is high.

$\begin{array}{cccc}1 & 2 & 3 & 4 \\ \text { 9. Learning English is a very easy task. } & 2 & 4 & 5\end{array}$

10. I try to study English to reach the highest level of ability in it.
1
2
3
4
5 
Hosseini, F. A., Pishghadam, R., \& Vahidnia, F. 